\title{
A Methodology to Estimate the Potential Production of Bioenergy Based on the Species, Cultivation Area Conditions, and Period of Forest Trees
}

\author{
Heesoo Lee ${ }^{\oplus}$. Seong-Rin $\operatorname{Lim}^{\dagger} \oplus$ \\ Department of Environmental Engineering, School of Architectural, Civil, and Environmental Engineering, Kangwon National \\ University, Chuncheon
}

(Received May 17, 2021; Revised May 21, 2021; Accepted May 24, 2021)

Introduction: Since the population increases and the industry develops, the demand for fossil fuels continues to increase, creating problems of energy resource depletions and accelerating global warming. Thus, many countries are making active efforts to replace fossil fuels with bioenergy as a renewable energy. In particular, trees managed and produced by forest industry have a high potential as energy sources for biofuel industry, because they have a conceptual characteristic of carbon neutrality. Recently, energy plan and policy are being developed to cultivate trees on fallow lands, environmentally restored sites, and ground-level work places of abandoned mines; however, economic feasibility for such plans and policies cannot be readily evaluated due to insufficient information on the amount of the energy to be produced from tree cultivation. Thus, the objective of this study is to develop a methodology which can be used to estimate the potential energy amount of the bioenergy from tree cultivation based on tree species, cultivation time, and cultivation area conditions.

Methodology: The methodology consists of three stages. In the first stage, the total volume of the trees per area is estimated by using the number of trees per unit area and the average stem volume of the tree, which are affected by the site index representing the environmental conditions of cultivation area. In the second stage, the total mass of biomass is calculated by using the density of wood, the biomass expansion factors for the above-ground biomass, and root-shoot ratio. In the last stage, the amount of the energy produced from the tree cultivation is estimated by taking into account the caloric value evaluated based on the carbon, hydrogen, and oxygen compositions of the tree.

Case Study: A case study for conifers and broad-leaved trees is performed to demonstrate the methodology. The conifers are Jungbu local pine, Korean white pine, and Japanese larch, and the broad-leaved trees are oak, red oak, and birch. The results of the case study validate the developed methodology and clearly showed the procedure and necessity for the methodology by estimating the bioenergy productions from the trees.

Conclusions: The developed methodology can be used to provide practical information needed to determine the economic feasibility of the plan, policy, and project for tree cultivations.

Keywords: Bioenergy, Biofuel, Energy Production, Forest Age, Forest Tree, Site Index

The Korean text of this paper can be translated into multiple languages on the website of http://jksee.or.kr through Google Translator.

Corresponding author
E-mail: srlim@kangwon.ac.kr
Tel: +82-33-250-6358 Fax: +82-33-259-5550
(c) 2021, Korean Society of Environmental Engineers 


\title{
연구논문
}

\section{임목의 수종, 재배지, 재배기간에 따라 생산할 수 있는 바이오에너지의 잠재량 평가 방법론}

\author{
이희수 ${ }^{\circledR} \cdot$ 임성린 $^{\dagger}$
}

강원대학교 건설토목환경공학부 환경공학전공

\begin{abstract}
서론 : 인구가 증가하고 산업이 발달하면서 화석 연료에 대한 수요는 계속해서 증가하여 에너지 자원의 고갈 문제 와 지구온난화를 가속시키는 문제를 발생시키고 있다. 이에 많은 국가들은 화석연료를 재생에너지인 바이오에너지 로 대체하기 위해 많은 노력을 하고 있다. 특히, 산림 산업에서 생산되는 임목은 탄소 중립의 개념적 특성을 가지 고 있기 때문에 펠렛과 같은 바이오연료로 높은 잠재력을 가지고 있다. 최근 휴경지, 환경복원지, 폐광산의 지상 작업장을 이용하여 임목을 생산하려는 계획이 활발히 진행되고 있으나 재배 지역이나 기간에 따라 생산할 수 있는 임목의 에너지 양에 대한 예측이 어려워 조림 사업의 경제성 평가가 어려운 실정이다. 이에 본 연구의 목적은 수 종, 재배 기간과 지역을 고려하여 단위 면적당 생산가능한 임목 바이오에너지의 잠재적인 양을 평가하는 방법론을 개발하는 것이다.
\end{abstract}

방법론 : 이 방법론의 첫 번째 단계에서는 임목의 수종, 재배 지역의 특성을 나타내는 지위지수, 재배 기간인 임령 자료를 바탕으로 재배 기간에 따른 임목의 평균 수간재적, 단위 면적당 임목의 개체수를 파악하여 임목의 총 재적 을 평가한다. 두 번째 단계에서는 목재의 밀도, 지상부의 바이오매스 양을 추산하는 바이오매스 확장계수, 뿌리-줄 기 비율을 이용하여 바이오매스 총 질량을 산정한다. 마지막 단계에서는, 수종별 목재의 탄소, 수소, 산소 조성을 고려한 단위 질량당 발열량을 평가하여 생산가능한 총 에너지 양을 산정한다.

사례연구: 이 방법론의 절차를 구체적으로 제시하기 위하여 국내의 대표적 침엽수와 활엽수를 대상으로 사례연구 를 실시하였다. 침엽수로 선정된 수종은 중부지방소나무, 잣나무, 낙엽송이었으며, 활엽수로 선정된 수종은 상수리 나무, 신갈나무, 자작나무이었다. 이 수종의 조림으로 인해 확보할 수 있는 바이오에너지 양을 평가하기 위한 세부 적인 과정을 제시함으로써 본 연구에서 개발된 방법론의 절차와 필요성을 구체적으로 보여주었다.

결론 : 본 연구에서 개발된 방법론은 임목 바이오에너지를 생산하기 위한 조림 사업의 경제성 평가에 반드시 필요 한 정보를 제공할 수 있므로 다양한 바이오연료를 생산하기 위해 필요한 바이오매스 자원을 확보하기 위한 정부의 재생에너지 정책이나 산림 산업에 기여할 수 있을 것이다.

주제어 : 바이오에너지, 바이오연료, 에너지 생산, 임령, 임목, 지위지수

\section{1. 서론}

인간의 화석연료 사용은 지구의 온도를 증가시키는 온실가 스를 계속하여 배출하여 지구온난화와 화석연료 고갈 문제에 직면하게 되었다. ${ }^{1)}$ 특히, 한국과 같이 에너지 자원이 부족한 국가는 수입에 의존하여 석유, 석탄, 천연가스를 얻고 있기 때문에 화석연료의 고갈은 경제적으로 큰 타격을 준다.2) 따라 서, 향후 온실가스를 배출하지 않고 자원 고갈의 염려가 없는 재생에너지 확보가 필요하다.

재생에너지 중에서 바이오에너지의 생산량은 지속적으로
증가하고 있으며, 그 중에서 목질계 바이오에너지를 상용화하 기 위해 다양한 기술개발이 이루어지고 있어 목질계 에너지 자원의 사용량이 점점 증가하고 있다. ${ }^{3-6)}$ 특히, 목재 펠렛의 사용이 증가하여 수입량은 계속해서 증가하고 있으나 국내에 서의 생산량은 매우 낮은 실정이다. ${ }^{7)}$ 이에 따라 국내에서도 목재 펠렛 생산 공장의 설립이 전국적으로 확산되고 있으나 원료로 사용할 수 있는 임목의 양이 부족하여 에너지로 활용 할 수 있는 임목의 재배가 필요하다. 자연 상태의 산림을 에너 지로 사용하는 것은 환경과 생태를 파괴시킬 수 있기 때문에 폐광산 지역, 휴경지, 환경복원지역과 같이 경제적으로 활용 
되지 않는 공간에 임목의 재배를 통하여 바이오에너지 원료를 확보하는 것이 필요하다. ${ }^{8)}$

임목과 같은 목질계 바이오매스는 다양한 종류의 친환경 연 료로 활용할 수가 있어 활용도가 매우 높은 재생가능한 에너 지 자원이다. 목질계 바이오매스는 그 자체로서 발전이나 난 방을 하기 위하여 필요한 스팀을 생산하기 위한 고체 에너지 로써 이용되기도 하지만 ${ }^{9)}$, 열분해를 통하여 합성가스, 오일, 바이오차와 같은 기체, 액체, 고체 연료로 각각 활용될 수 있 다. ${ }^{10)}$ 또한, 목질계 바이오매스는 셀룰로오스 분해효소를 통 해 전처리를 된 후 당화 효소와 효모를 이용하여 자동차 연료 로 사용할 수 있는 바이오에탄올로 전환될 수 있다. ${ }^{11)}$ 이처럼 목질계 바이오매스의 확보는 다양한 종류의 연료로 활용될 수 있기 때문에 국내에서는 임목 생산량을 증가시키기 위한 노력이 요구된다.

임목의 생산량은 수종뿐만 아니라 재배 지역의 환경과 재배 기간에 영향을 받기 때문에 임목 생산량의 정확한 평가는 조 림 사업의 투자에 대한 경제성을 평가하는데 있어서 가장 중 요한 판단 근거가 된다. 하지만, 수종에 따라서 임목의 직경이 나 수고 성장률이 매우 다르며 ${ }^{12,13)}$, 재배 지역의 기온, 강수량, 일조량 등 환경 조건은 임목의 생산량에 큰 영향을 미친 다. ${ }^{13,14)}$ 또한, 단위 면적에서 성장하는 임목의 수종별 개체수 도 재배 기간에 따라 큰 영향을 받는다. ${ }^{13,15}$ 즉, 임령이 길어질 수록 단위 면적당 임목의 수는 감소하게 된다. ${ }^{13)}$ 따라서, 임목 은 시간에 따라 일정한 속도로 성장하지 않기 때문에 임목 자원을 효과적으로 생산하기 위해서는 성장속도가 빠른 시기 에는 바이오매스의 축적을 유도하고, 성장속도가 느려지는 시 기에는 벌채하여 새로운 묘목을 다시 식재하는 것이 바람직하 다. 따라서, 임목 바이오에너지의 생산을 위한 조림 사업에 대한 경제적 타당성을 판단하기 위해서는 다양한 수종과 재배 조건에 따라 확보할 수 있는 에너지의 양을 평가하는 것이 반드시 필요하다.

본 연구의 목적은 수종, 재배 기간, 재배 지역의 환경조건을 고려하여 단위 면적당 생산가능한 임목 바이오매스의 잠재적 인 에너지 양을 평가하는 방법론을 개발하는 것이다. 이 방법 론에서는 재배하려는 수종을 먼저 선정한 후, 재배 지역의 환 경조건을 나타내는 지위지수, 재배 기간인 임령, 단위 면적당 임목의 개체수를 고려하여 임목의 총 재적을 평가한다. 그 다 음 단계에서는 이전 단계의 결과를 바탕으로 임목의 밀도, 지 상부의 바이오매스 확장계수 ${ }^{16)}$, 뿌리-줄기 비율 ${ }^{17)}$ 을 이용하여 임목 바이오매스의 총 질량을 산정한다. 마지막 단계에서는 수종별로 목재의 화학조성을 이용하여 바이오매스의 단위 질 량당 발열량을 고려하여 조림을 통하여 생산이 가능한 총 에 너지 양을 평가한다. 이렇게 개발된 방법론의 수행 절차를 구 체적으로 제시하기 위하여 국내의 대표적인 침엽수종과 활엽 수종을 대상으로 사례연구를 실시하였다. 본 연구 결과들은 임목 바이오에너지를 생산하기 위해 필요한 경제성 평가에

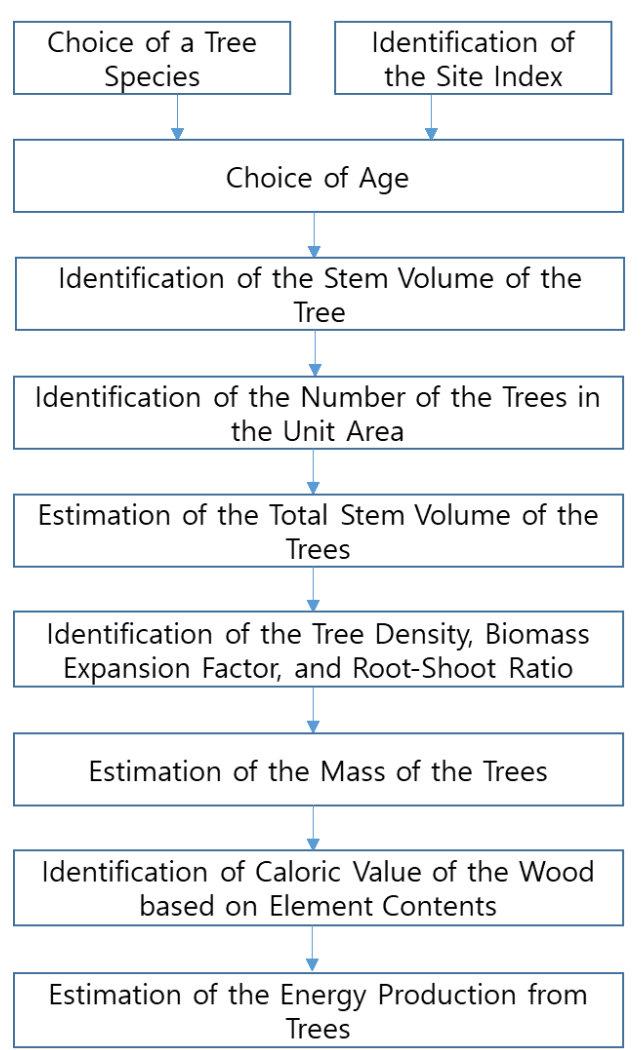

Fig. 1. Overview of the methodology to estimate the amount of biomass energy production depending on tree species, tree age, and forest site index.

반드시 필요한 정보를 제공할 수 있어 바이오에너지 자원을 확보하기 위한 계획, 정책, 사업의 개발에 활용할 수 있다.

\section{2. 방법론}

임목을 재배하려는 토지의 단위 면적당 생산할 수 있는 바 이오매스의 잠재적인 에너지 양을 평가하기 위해 개발한 방법 론의 절차가 Fig. 1 에 제시되어 있다. 임목의 수종과 재배 기간 과 환경조건에 따라 임목의 직경과 수고가 달라질 뿐만 아니 라 바이오매스의 성장속도가 달라지기 때문에 먼저 재배하려 는 임목의 수종을 선택한다. 임목의 성장은 재배하는 토지의 환경 조건에 영향을 많이 받기 때문에 재배하려는 토지의 다 양한 특성을 정량화하여 나타내는 지위지수(Site Index: SI)를 결정하여야 한다. ${ }^{18)}$ 이 지위지수는 수종별로 재배 지역의 지 형, 기후대, 모암(parent rock), 토양 배수, 경사, 표고, 퇴적양 식, 침식상태, 경사형태, 방위, 유효 토심, 암성 노출도, 능선 대 계곡비, 풍노충도, 풍화정도, 토양형, 토심, 토색, 유기물, 토성, 건습도, 견밀도 등에 영향을 받아 결정된다. ${ }^{19)}$ 국내에서 의 수종별 지위지수를 결정하기 위해서는 국립산림과학원의 지위지수 추정식을 활용할 수 있다. ${ }^{19)}$ 다음 단계에서는 재배 하려는 기간을 결정하여 임목의 수확 시점에서 확보할 수 있 는 바이오에너지 양을 평가하기 위한 시간적 기준을 설정한 
Table 1. Tree species selected for the case study.

\section{Tree species}

Conifer

Jungbu local pine, Korean white pine, Japanese larch

Broad-leaved Tree

Oak, red oak, birch

다. 이 재배 기간에 따라서 수종별 지위지수를 반영하여 수간 재적표(stem volume table)를 이용하여 줄기의 부피인 수간재 적을 산정한다. ${ }^{13)}$ 또한, 이 재배 시점에서의 단위 면적당 임목 의 개체수도 결정된다. ${ }^{13)}$ 다음으로는 임목의 수간재적과 단위 면적당 개체수를 이용하여 단위 면적당 확보할 수 있는 임목 의 총 수간재적을 다음 식 (1)과 같이 계산한다.

$$
\mathrm{TSV}=\mathrm{SV} \times \mathrm{NT}
$$

여기서, TSV는 단위 면적당 총 수간재적, $\mathrm{SV}$ 는 임목 개체 의 단위 수간재적, NT는 단위 면적당 임목의 개체수이다. 여 기서 평가된 단위 면적당 총 수간재적은 임목의 기본 밀도, 바이오매스 확장계수(biomass expansion factor) ${ }^{16)}$, 뿌리-줄기 비율(root-shoot ratio) ${ }^{17)}$ 를 이용하여 다음 식 (2)와 같이 단위 면적당 임목의 총 질량을 산정한다.

$$
\mathrm{TM}=\mathrm{TSV} \times \mathrm{D} \times \mathrm{BEF} \times(1+\mathrm{RSR})
$$

여기서, $\mathrm{TM}$ 은 단위 면적당 임목의 총 질량, $\mathrm{D}$ 는 임목의 밀 도, $\mathrm{BEF}$ 는 바이오매스 확장 계수, RSR은 뿌리-줄기 비율이다. 임목은 구성 원소의 성분에 따라 발열량이 달라지므로 수종별 로 임목의 원소 조성인 탄소, 수소, 산소 등의 함량을 평가하 여 임목의 단위 질량당 발열량을 평가하고, 이를 이용하여 단 위 면적당 임목의 총 질량은 단위 면적당 생산할 수 있는 에너 지의 양으로 다음 식 (3)을 이용하여 변환된다.

$$
\mathrm{TEP}=\mathrm{TM} \times \mathrm{CV}
$$

여기서, TEP은 단위 면적당 총 임목의 생산 에너지 양, TM 은 단위 면적당 임목의 총 질량, $\mathrm{CV}$ 은 임목의 단위 질량당 발열량이다. 단위 질량당 발열량은 수종의 화학적 원소 조성 을 이용하여 Ruyter식 ${ }^{20)}$, Dulong 식 ${ }^{21,22)}$, Steuer식 ${ }^{21)}$ 등을 이용 하여 열량을 추정할 수 있다.

\section{3. 사례연구}

본 연구에서 개발된 방법론의 적용 가능성을 증명하고 방법 론의 절차를 구체화하기 위하여 사례연구를 통해 국내의 대표 적인 수종들에 대하여 재배 기간에 따른 바이오에너지의 생산 량을 평가하였다.

\section{1. 평가 대상 임목의 선정}

사례연구를 위하여 선정한 수종은 Table 1에 나타난 바와
같이 국내에서 식재를 하고 있는 대표적인 수종인 침엽수 3종 (중부지방소나무, 잣나무, 낙엽송)과 활엽수 3종(상수리나무, 신갈나무, 자작나무)이다. 이 수종들의 재배 기간에 따른 평균 직경 변화 ${ }^{13)}$ 는 Fig. 2와 같다. 모든 침엽수들의 시간에 따른 평균 직경은 초기에는 가파른 증가를 보이다가 어느 정도의 성장이 이루어졌을 때에서는 증가 속도가 낮아지는 로그함수 형태의 증가 경향을 보였다. 활엽수의 평균 직경은 성장 시기 와는 비교적 무관하게 일정한 속도를 보여 선형적인 증가를 보였다. 임목 직경의 성장은 수종에 관계없이 지위지수가 높 을수록 성장 환경이 우수하여 직경이 크다는 것을 알 수 있으 며, 침엽수와 비교하여 활엽수의 직경 성장은 전반적으로 지 위지수의 영항을 적게 받는다는 것을 알 수 있다. 재배 기간에 따른 임목의 평균 수고 ${ }^{13)}$ 도 Fig.3에 나타내었다. 모든 침엽수 들의 평균 수고도 평균 직경처럼 로그함수의 증가 경향을 보 여주었고, 활엽수의 평균 직경도 성장 시기 전반에 걸쳐 선형 적인 증가를 보여 주었다. 임목 수고의 성장도 직경의 성장처 럼 수종에 관계없이 지위지수가 높을수록 우수하였다. 또한, 활엽수의 수고 성장도 침엽수보다 지위지수의 영향을 적다는 것을 알 수 있다.

\section{2. 수간재적 변화}

선정한 수종의 평균 직경과 수고를 기준으로 수간재적표 ${ }^{13)}$ 를 이용하여 개별 임목의 평균 줄기 부피인 수간재적을 산정 하여 Fig.4와 같이 나타내었다(Fig.4(e)에서 지위지수별 변화 가 서로 겹치는 것은 원자료의 통계적 오차에 기인함). 수종에 관계없이 수간재적의 증가는 재배 기간이 길어질수록 점점 더 많이 증가하는 것을 알 수 있다. 이런 증가 경향은 임목의 직경이나 수고의 증가와는 다른 형태를 보여 주었다. 또한, 재배 기간이 길어질수록 대부분의 수종에 대하여 지위지수가 높은 재배지에서의 수간재적이 크게 증가되는 것을 알 수 있 다. 하지만, 수간재적의 시간에 따른 변화량을 파악할 수 있더 라도 재배 기간에 따라서 단위 면적당 자라는 임목의 개체수 가 달라지므로 바이오매스의 양을 평가하기 위해서는 개체수 에 대한 고려가 필요하다.

\section{3. 단위 면적당 개체수의 변화}

임목의 재배기간에 따른 단위 면적당 개체수의 변화를 수종 별로 Fig.5에 나타내었다. 재배 기간이 경과함에 따라서 임목 의 직경, 수고, 수간재적이 모두 증가하지만 일정한 면적에서 자라는 임목의 개체수가 감소함을 알 수 있다. 재배 기간의 


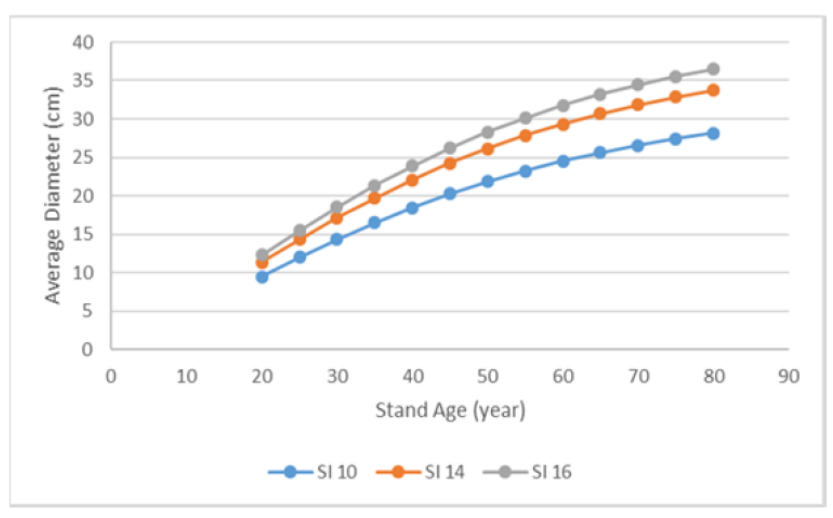

(a)

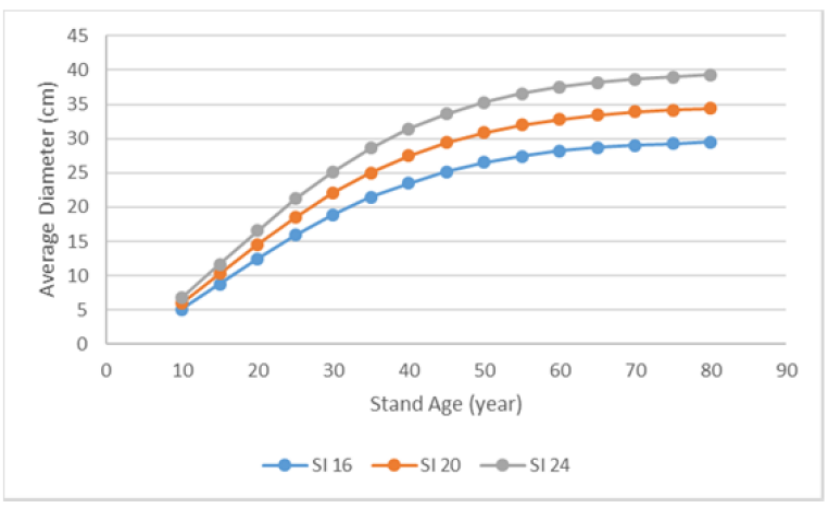

(c)

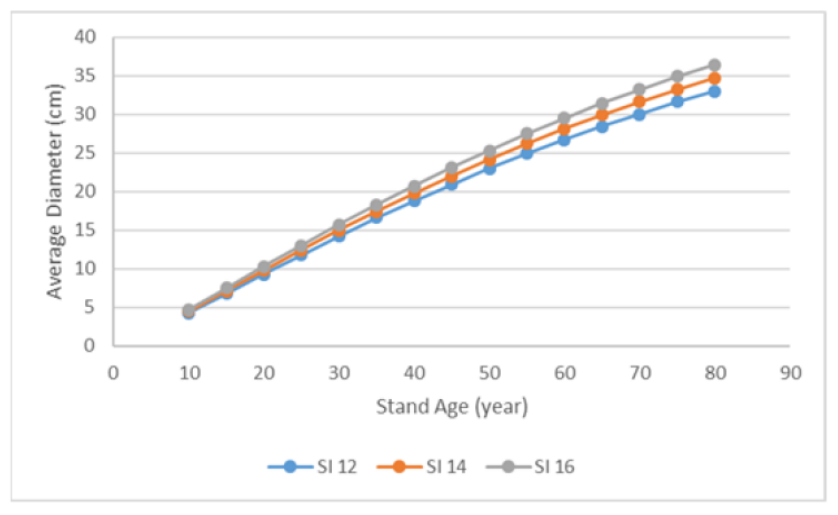

(e)

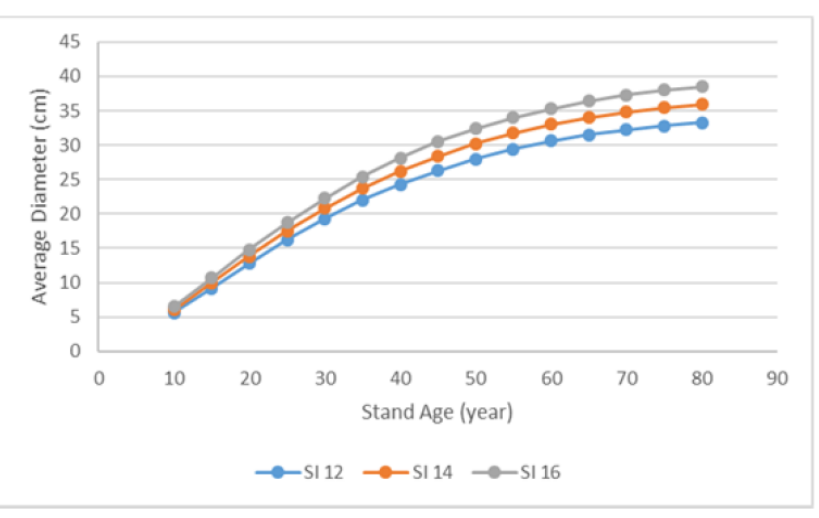

(b)

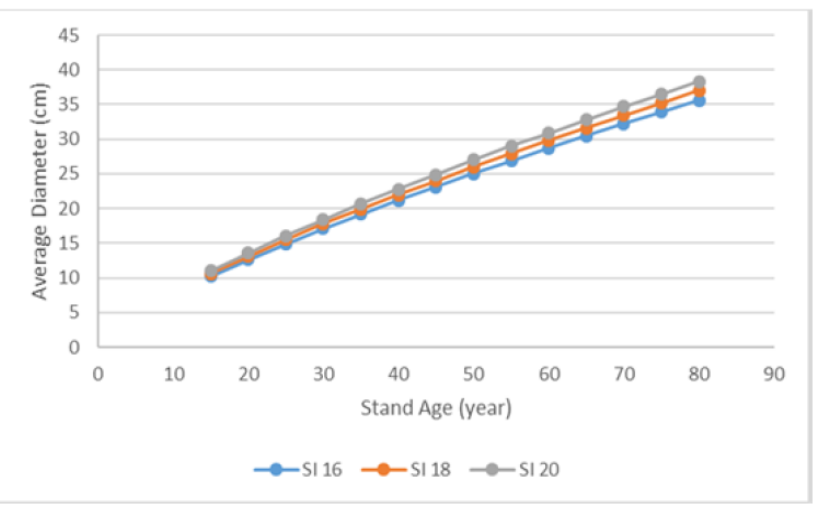

(d)

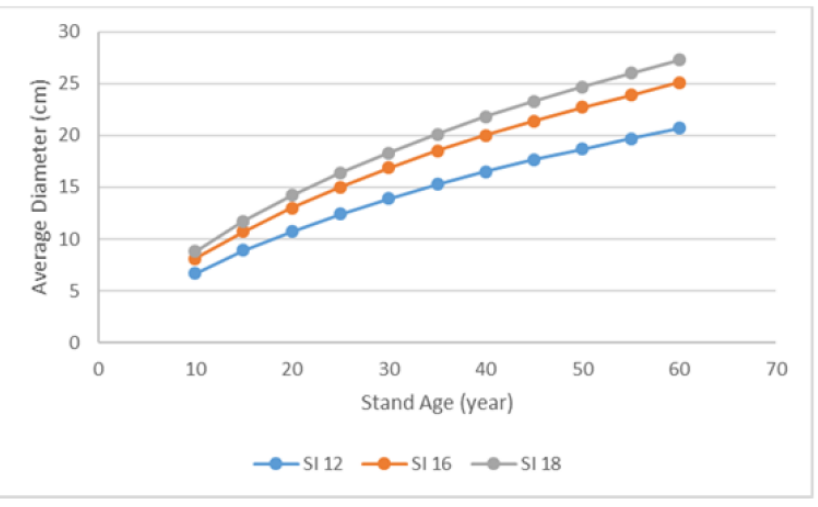

(f)

Fig. 2. Temporal variation of average diameter of the selected trees depending on the site index (SI) representing the environmental conditions of cultivation area: (a) Jungbu local pine; (b) Korean white pine; (c) Japanese larch; (d) oak; (e) red oak; and (f) birch. Due to data availability, the data for each tree are based on the different Sls (data source: Korea Forest Service/Korea National Institute of Forest Science $\left.{ }^{13}\right)$.

초기에 수종에 관계없이 모두 개체수가 급격히 감소하다가 일정한 시점 이후부터는 감소 속도가 줄어든 후 개체수가 안 정화되는 것을 알 수 있다. 이러한 경향은 대부분의 침엽수와 활엽수에서 매우 뚜렷하게 나타났다.

\section{4. 단위 면적당 수간재적의 변화}

임목 개체의 수간재적의 변화와 단위 면적당의 개체수 변화 를 함께 고려한 단위 면적당 수간재적의 변화를 식 (1)을 이용
하여 산정한 다름 Fig.6에 나타내었다. 침엽수들은 어느 시점 이후부터는 증가속도가 감소하는 로그 함수 형태의 증가를 보였고, 활엽수들은 시간에 따라 단위 면적당 수간재적이 선 형에 가깝게 증가하는 것을 보였다.

\section{5. 단위 면적당 바이오매스 질량의 변화}

각 수종별 밀도, 바이오매스 팽창계수, 뿌리-줄기 비율을 이 용하여 에너지로 사용할 수 있는 바이오매스의 질량을 평가하 


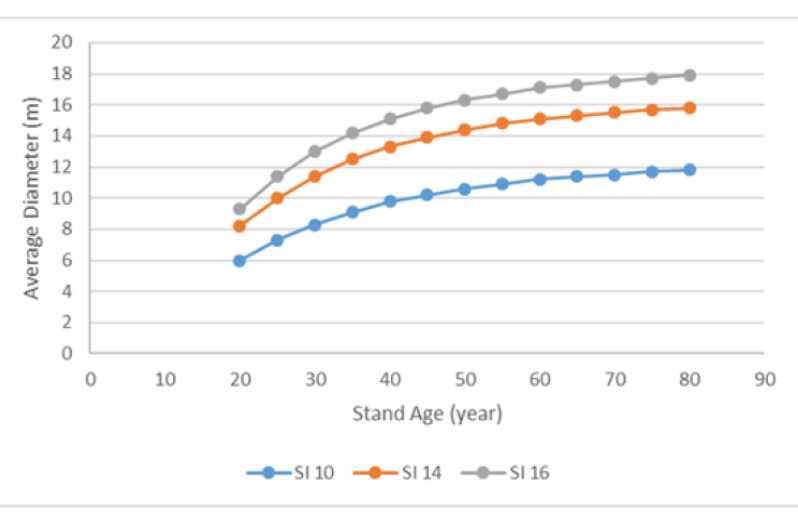

(a)

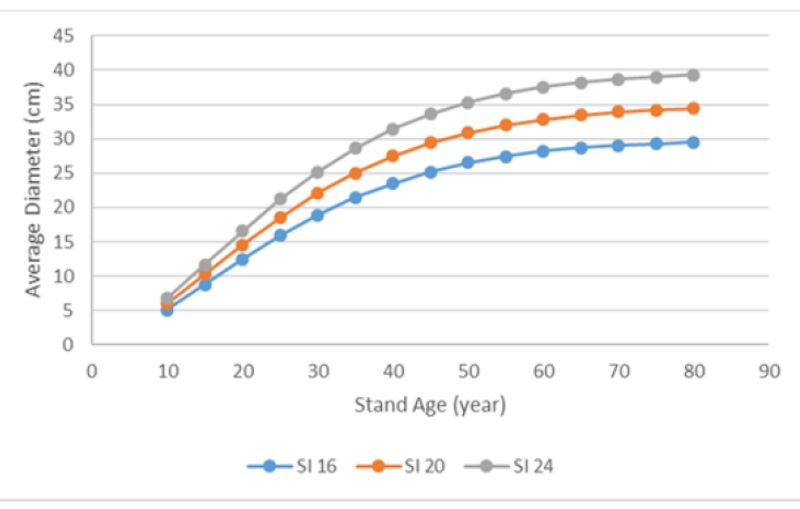

(c)

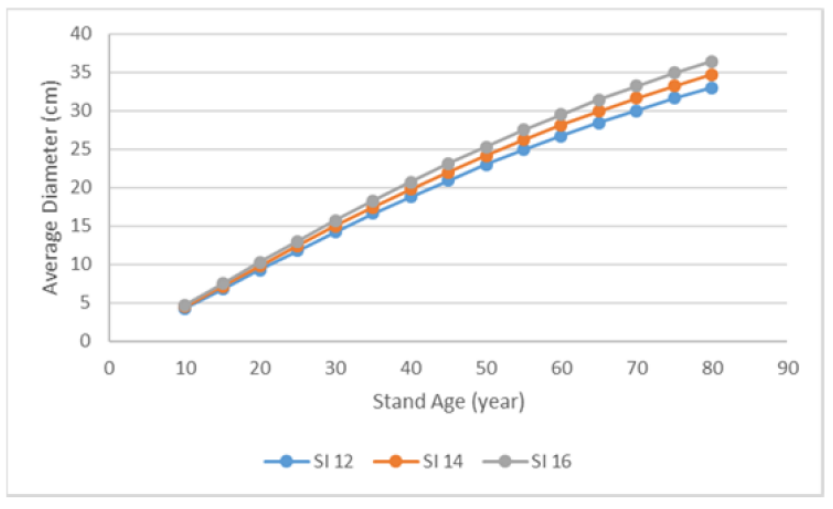

(e)

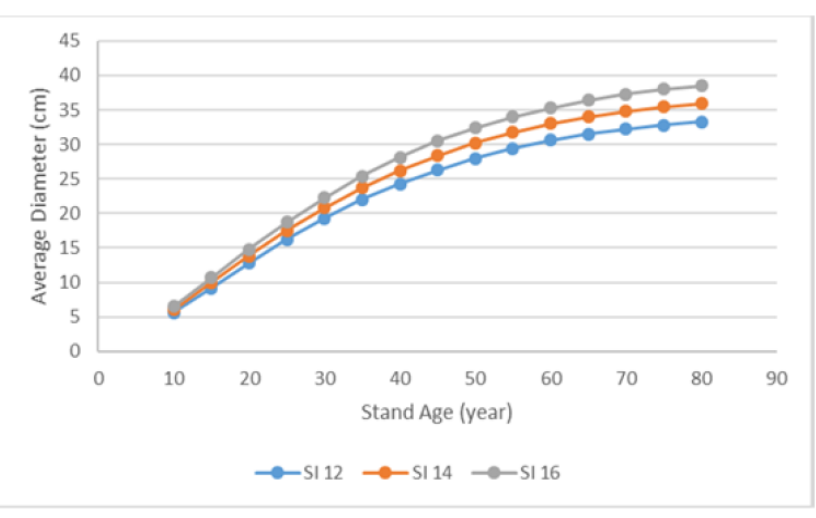

(b)

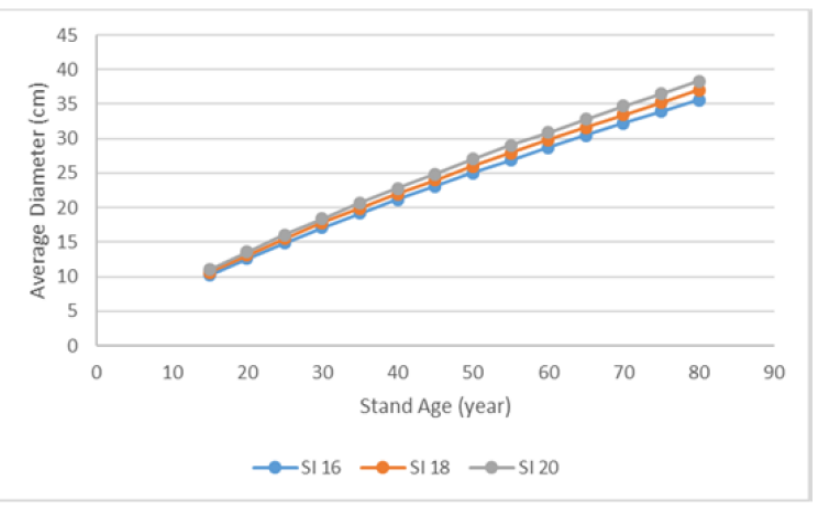

(d)

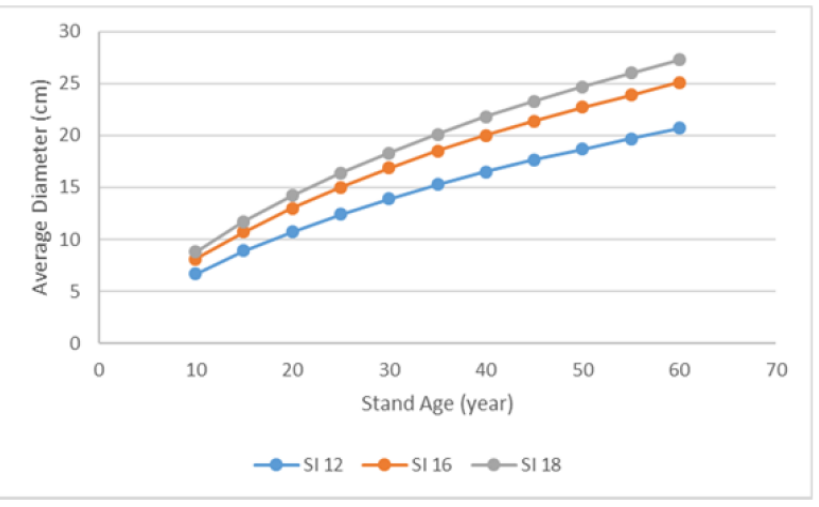

(f)

Fig. 3. Temporal variation of average height of the selected trees depending on the site index (SI) representing the environmental conditions of cultivation area: (a) Jungbu local pine; (b) Korean white pine; (c) Japanese larch; (d) oak; (e) red oak; and (f) birch. Due to data availability, the data for each tree are based on the different SIs (data source: Korea Forest Service/Korea National Institute of Forest Science ${ }^{13)}$ ).

였다. Table 2는 이 평가에서 사용한 수종별 밀도, 바이오매스 팽창계수, 뿌리-줄기 비율을 나타낸다. 수종별로 밀도를 비교 해 보면 침엽수보다는 활엽수의 밀도가 상대적으로 높은 것을 알 수 있다. 바이오매스 팽창계수를 비교해 보면, 잣나무와 신갈나무가 높은 값을 가지고 있고 잣나무와 자작나무의 값이 낮은 것을 알 수 있다. 뿌리-줄기의 비율의 경우, 활엽수가 침 엽수보다 높은 것을 알 수 있다. 이와 같이 수종별로 밀도, 바이오매스 팽창계수, 뿌리-줄기 비율이 매우 다르기 때문에
식 (2)를 이용하여 에너지로 사용할 수 있는 단위면적당 바이 오매스 질량을 계산하여 재배 시간에 따른 변화를 Fig.7에 나타내었다(Fig.7(e)에서 지위지수별 변화가 서로 겹치는 것 은 원자료의 통계적 오차에 기인함). 중부지방소나무와 낙엽 송은 로그함수 형태의 증가 경향을 보였으나, 나머지 수종들 은 모두 선형함수 형태의 증가 경향을 보였다. 


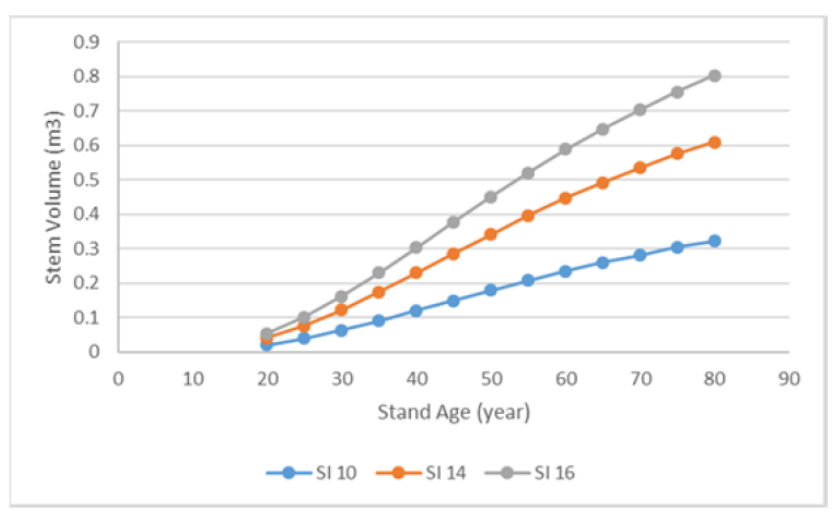

(a)

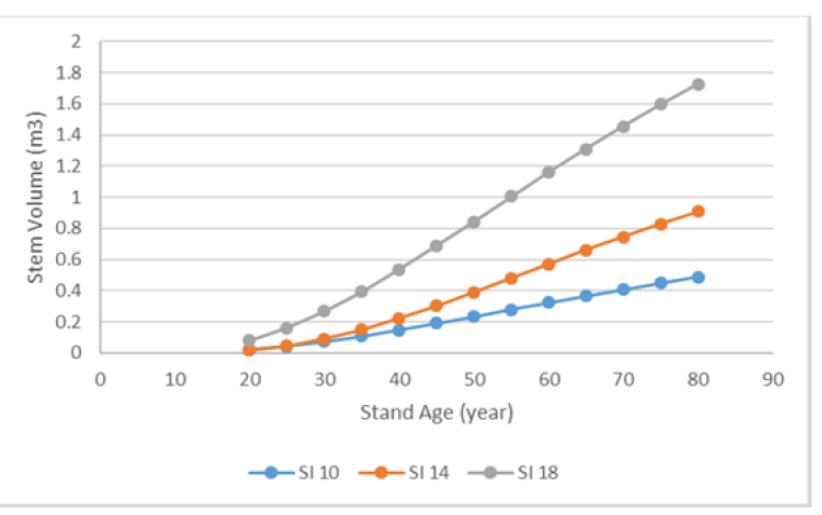

(c)

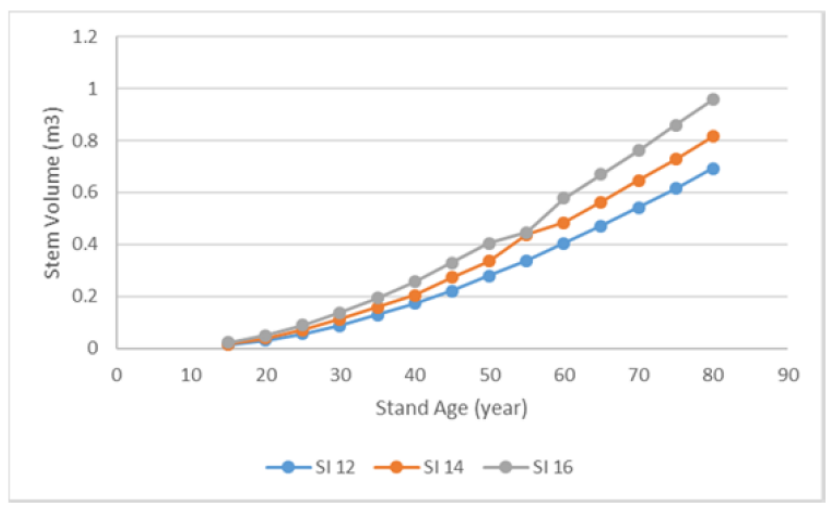

(e)

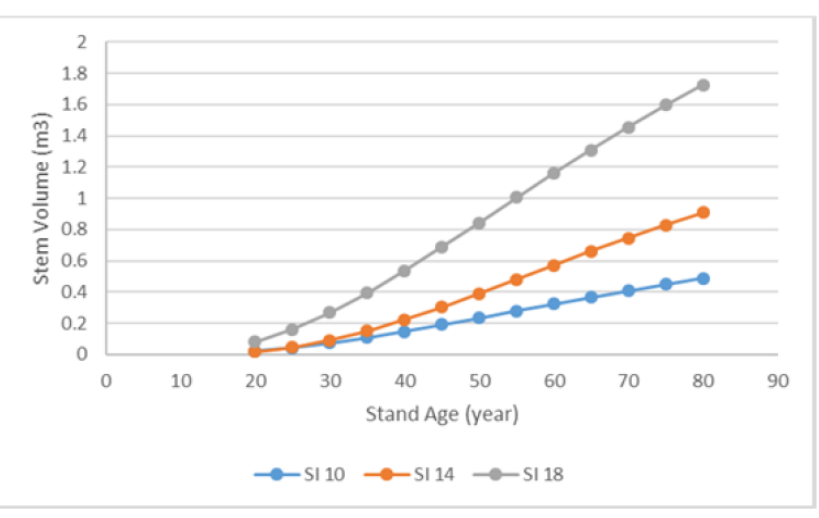

(b)

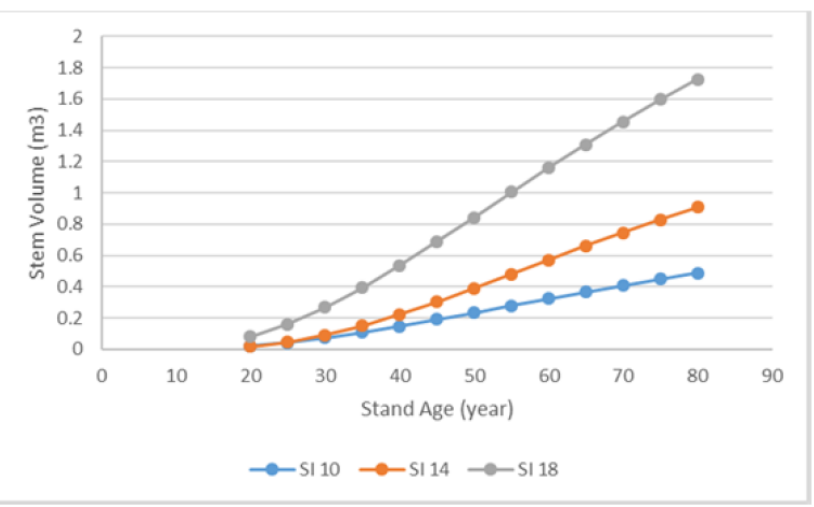

(d)

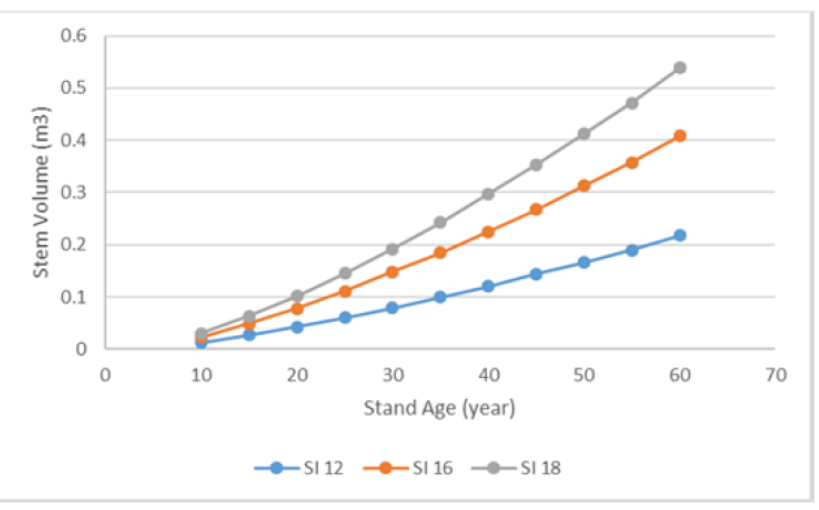

(f)

Fig. 4. Temporal variation of the stem volume of a tree depending on the site index (SI) representing the environmental conditions of cultivation area: (a) Jungbu local pine; (b) Korean white pine; (c) Japanese larch; (d) oak; (e) red oak; and ( $f$ ) birch. Due to data availability, the data for each tree are based on the different Sls (data source : Korea Forest Service/Korea National Institute of Forest Science ${ }^{13)}$ ).

Table 2. Density, biomass expansion factor, root-shoot ratio of the trees. $^{23)}$

\begin{tabular}{cccc} 
& Density & Biomass expansion factor & Root-shoot ratio \\
Jungbu local pine & 0.472 & 1.413 & 0.254 \\
\hline Korean white pine & 0.408 & 1.812 & 0.283 \\
\hline Japanese larch & 0.453 & 1.335 & 0.291 \\
\hline Oak & 0.721 & 1.450 & 0.313 \\
\hline Red oak & 0.633 & 1.603 & 0.388 \\
\hline Birch & 0.588 & 1.388 & 0.349 \\
\hline
\end{tabular}




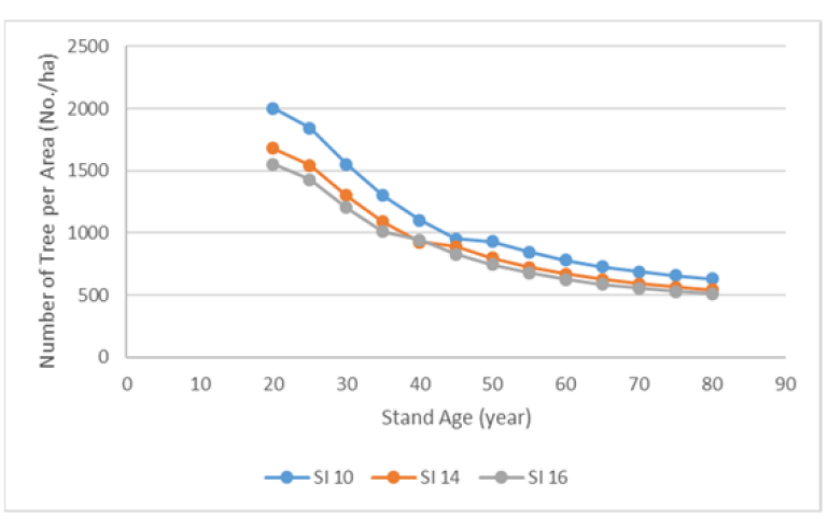

(a)

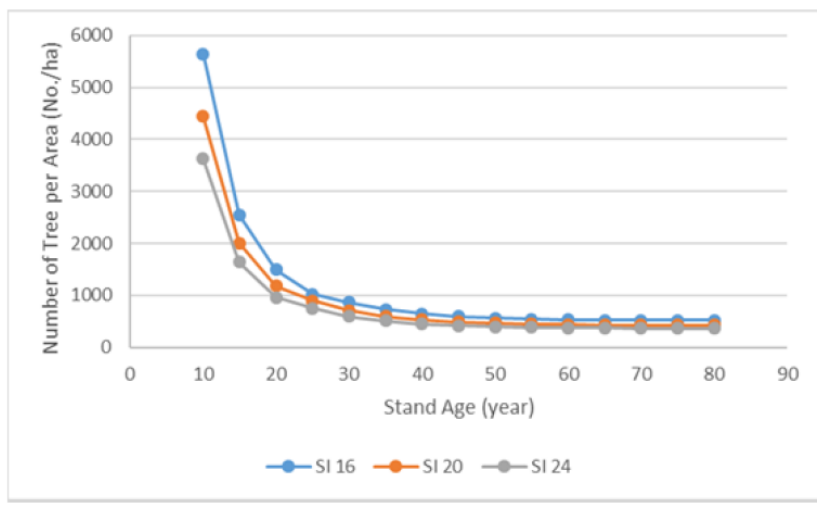

(c)

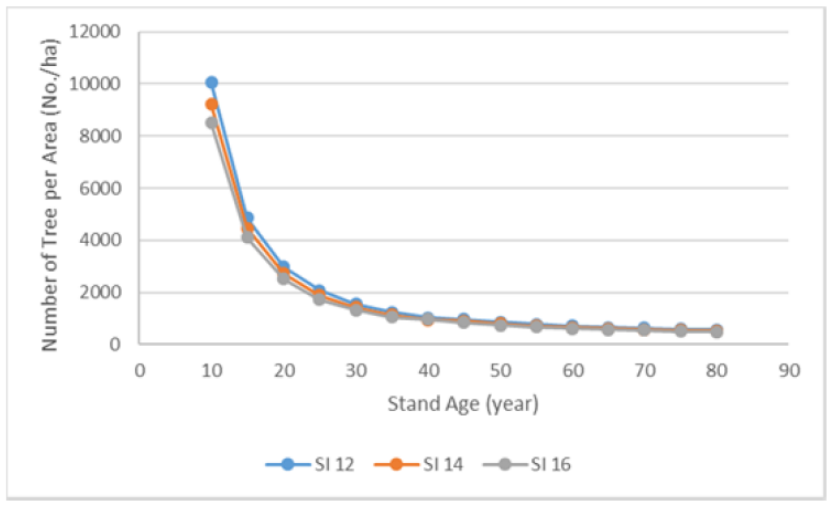

(e)

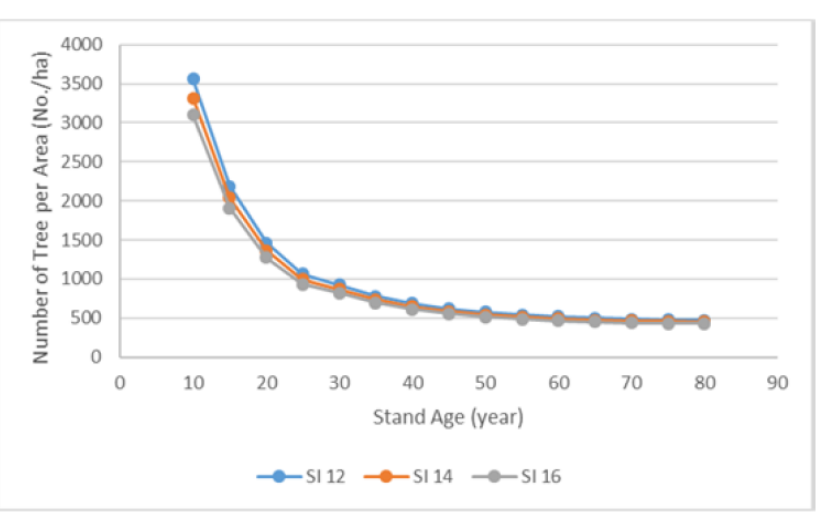

(b)

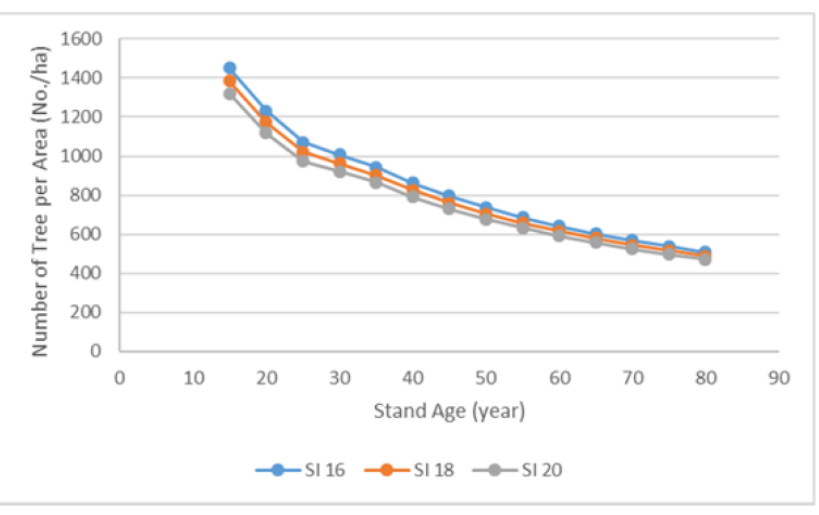

(d)

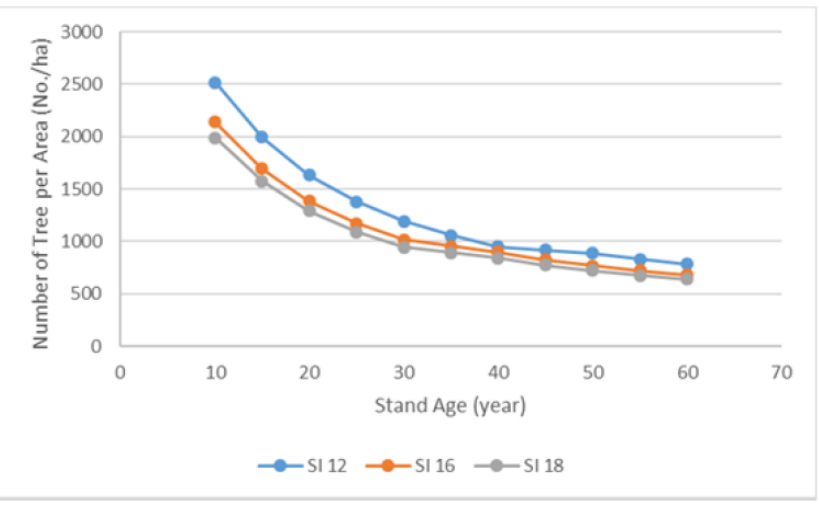

(f)

Fig. 5. Temporal variation of the number of the trees per area depending on the site index (SI) representing the environmental conditions of cultivation area: (a) Jungbu local pine; (b) Korean white pine; (c) Japanese larch; (d) oak; (e) red oak; and (f) birch. Due to data availability, the data for each tree are based on the different Sls (data source : Korea Forest Service/Korea National Institute of Forest Science ${ }^{13)}$ ).

\section{6. 단위 면적당 에너지 생산량의 변화}

수종별로 단위 질량당 발열량이 다르기 때문에 임목의 원소 함량을 고려하여 단위 면적당 생산할 수 있는 바이오에너지의 양을 평가하여 Fig. 8과 같이 재배 시간의 변화에 따라 나타내 었다. 수종별 단위 질량당 발열량을 구하기 위하여 수종의 탄 소, 수소, 산소의 함량을 이용하였으며, 이 평가에서 사용한 수종별 원소 함량 비유은 Table3과 같다. 임목을 구성하는 원 소 성분은 주로 탄소와 산소인 것으로 나타났으며 그 다음으
로는 수소가 존재하였다. 이 이외의 질소, 황과 같은 원소 성 분들은 무시할 수준으로 존재하였다. 본 사례연구에서는 이 주요 성분들의 구성비율을 바탕으로 아래의 식 (4)와 같이 Ruyter 식 ${ }^{20)}$ 을 이용하여 산정한 단위 질량당 발생량과 단위 재배면적당 바이오매스 질량을 이용하여 단위 면적당 바이오 에너지의 생산량을 평가한 결과, 잣나무, 상수리나무, 신갈나 무, 자작나무는 시간의 변화에 따라 거의 선형적인 증가를 보 여 주었으며, 중부지방소나무와 낙엽송은 로그 함수 형태의 


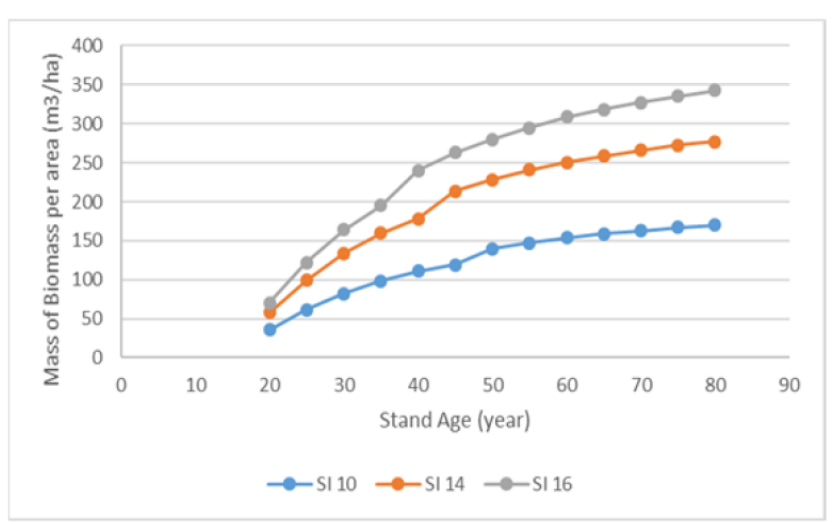

(a)

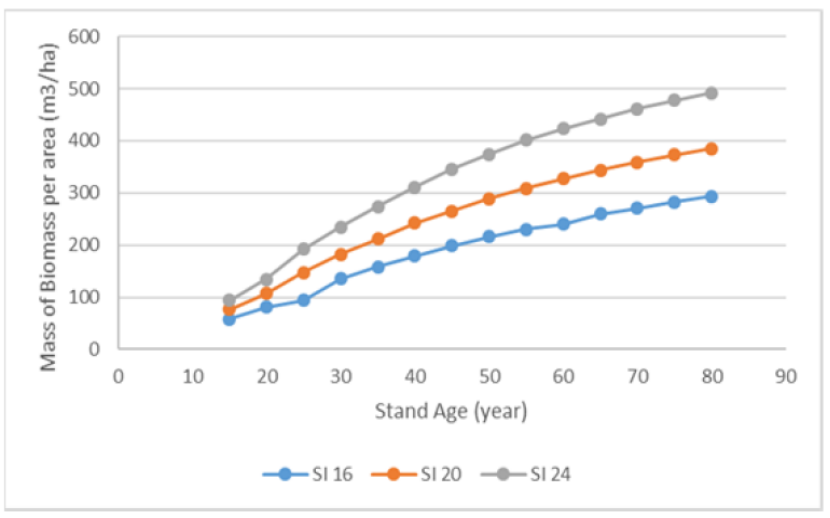

(c)

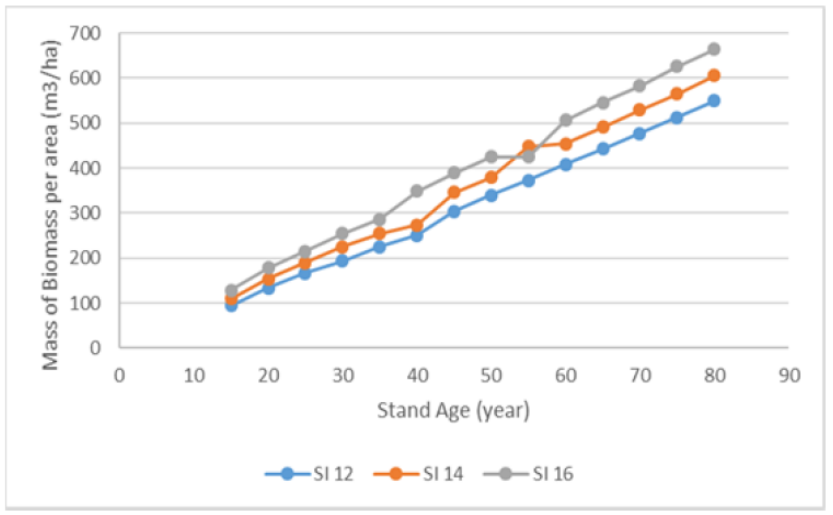

(e)

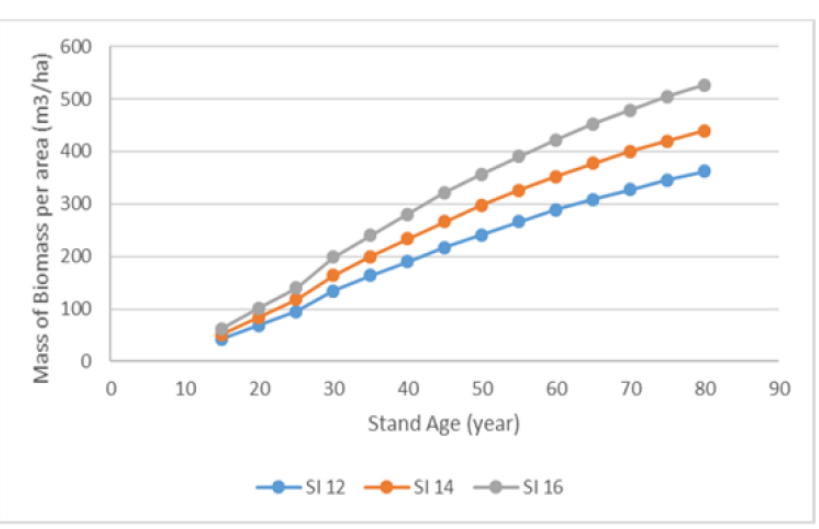

(b)

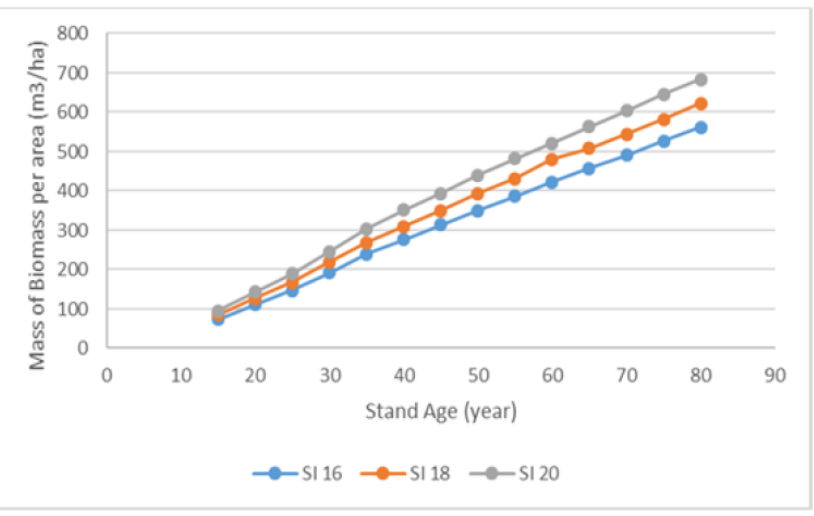

(d)

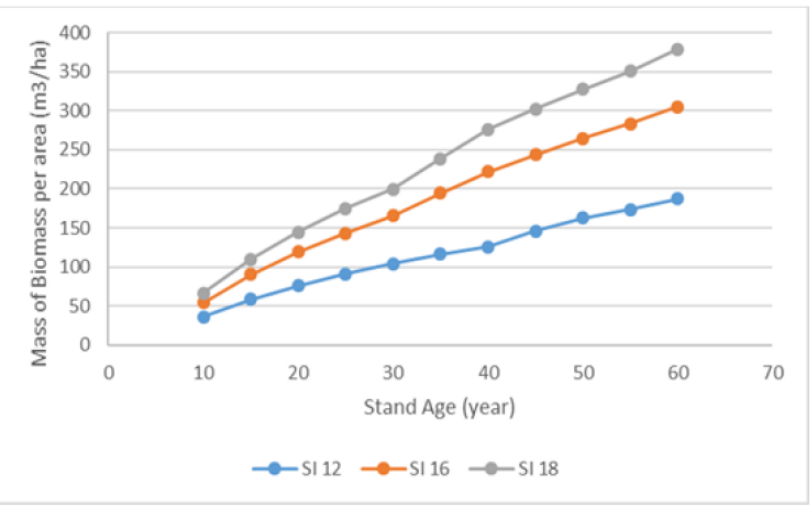

(f)

Fig. 6. Temporal variation of the total stem volume of the trees per area depending on the site index (SI) representing the environmental conditions of cultivation area: (a) Jungbu local pine; (b) Korean white pine; (c) Japanese larch; (d) oak; (e) red oak; and (f) birch. Due to data availability, the data for each tree are based on the different Sls.

Table 3. Element compositions of the trees for carbon, hydrogen, and oxygen. ${ }^{24)}$

\begin{tabular}{cccc} 
& $\mathrm{C}(\%)$ & $H(\%)$ & $0(\%)$ \\
Jungbu local pine & 49.5 & 6.7 & 43.7 \\
\hline Korean white pine & 47.7 & 6.4 & 45.9 \\
\hline Japanese larch & 47.9 & 6.3 & 45.8 \\
\hline Oak & 45.2 & 6.4 & 48.2 \\
\hline Red oak & 49.5 & 6.7 & 43.7 \\
\hline Birch & 46.0 & 6.3 & 47.6 \\
\hline
\end{tabular}




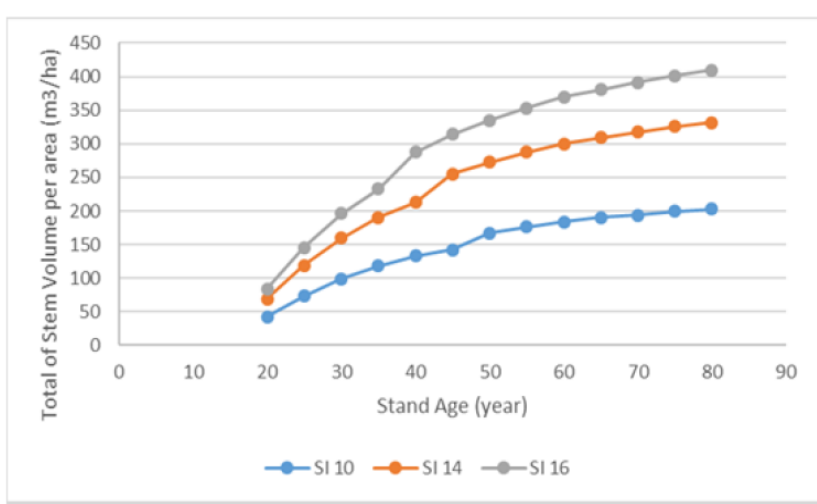

(a)

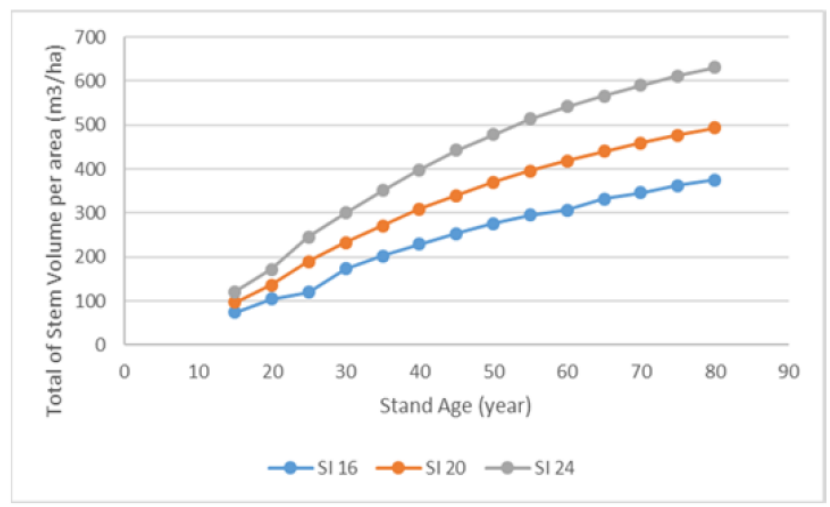

(c)

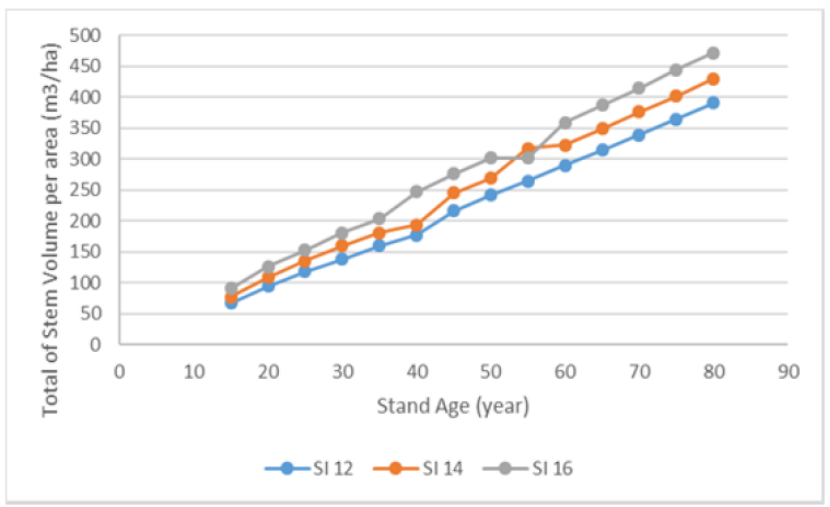

(e)

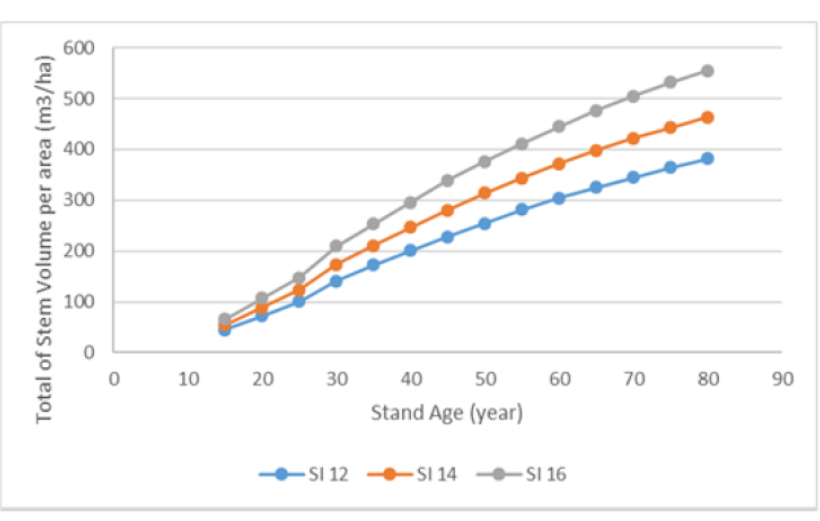

(b)

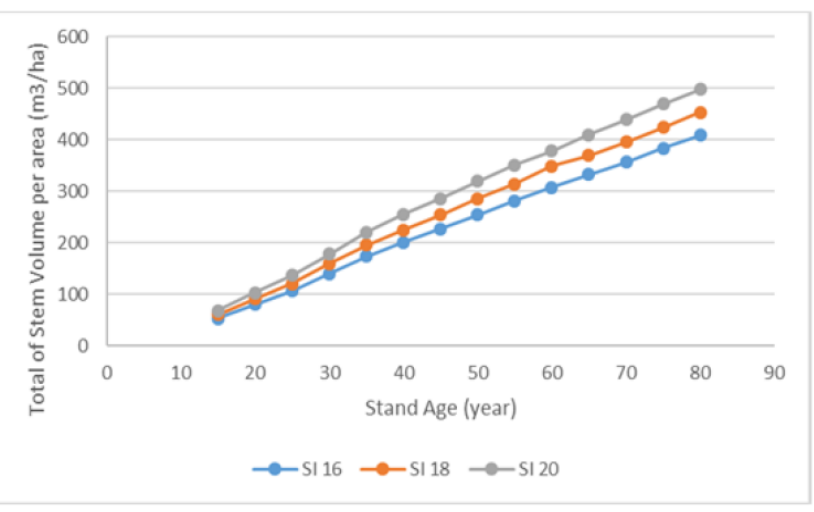

(d)

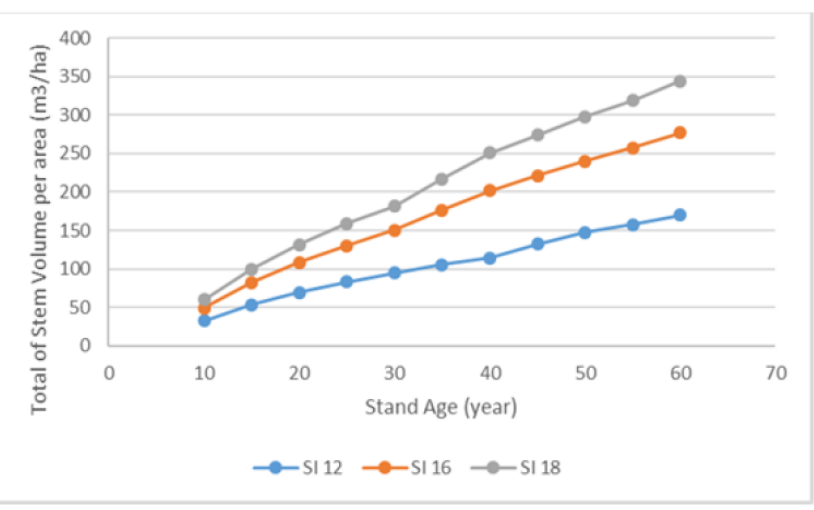

(f)

Fig. 7. Temporal variation of the total mass of the biomass from the trees per area depending on the site index (SI) representing the environmental conditions of cultivation area: (a) Jungbu local pine; (b) Korean white pine; (c) Japanese larch; (d) oak; (e) red oak; and ( $f$ ) birch. Due to data availability, the data for each tree are based on the different Sls.

증가를 보여 주었다. 최종적으로 얻은 이 결과를 이용함으로 써 재배 기간에 따라 생산할 수 있는 바이오에너지의 양을 예 측할 수 있으며, 목표로 하는 에너지 생산량을 확보하기 위해 서 필요한 재배 기간도 평가할 수 있음을 알 수 있다.

$$
\mathrm{CV}(\mathrm{MJ} / \mathrm{kg})=0.34 \times \mathrm{C}(\%)+1.40 \times \mathrm{H}(\%)-0.16 \times \mathrm{O}(\%)
$$

여기서, C, H, O는 탄소, 수소, 산소의 질량비율(\%)을 나타 낸다.

\section{4. 결 론}

황폐화된 솦, 휴경지, 환경복원지, 폐광산의 지상 공간과 같 이 활용되지 않는 토지를 이용하여 재생에너지 자원으로 활용 이 가능한 임목 바이오에너지를 생산하고자 하는 사업의 경제 적 타당성을 평가하기 위해 수종별 에너지 생산량을 예측하기 위한 방법론을 제시하였다. 또한, 사례연구를 통하여 이 방법 론의 필요성과 절차를 구체적으로 보여줄 수 있도록 국내 대 표 수종에 대하여 재배 기간에 따른 에너지 생산량을 산정하 


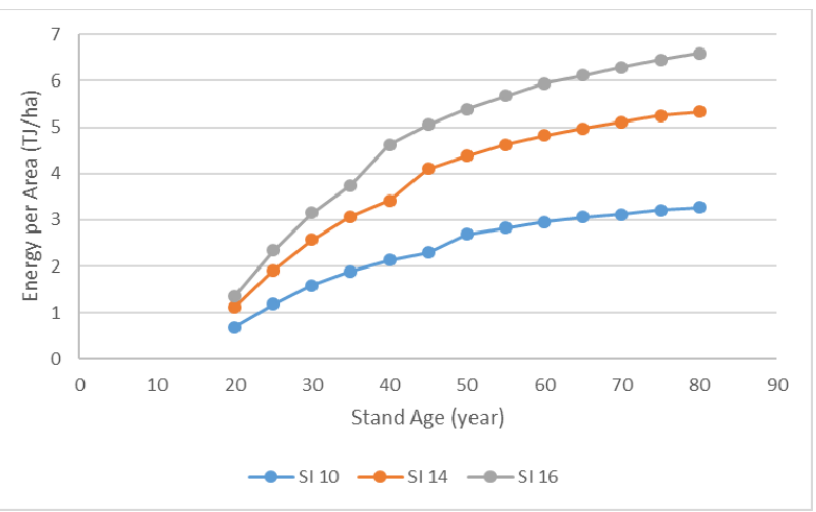

(a)

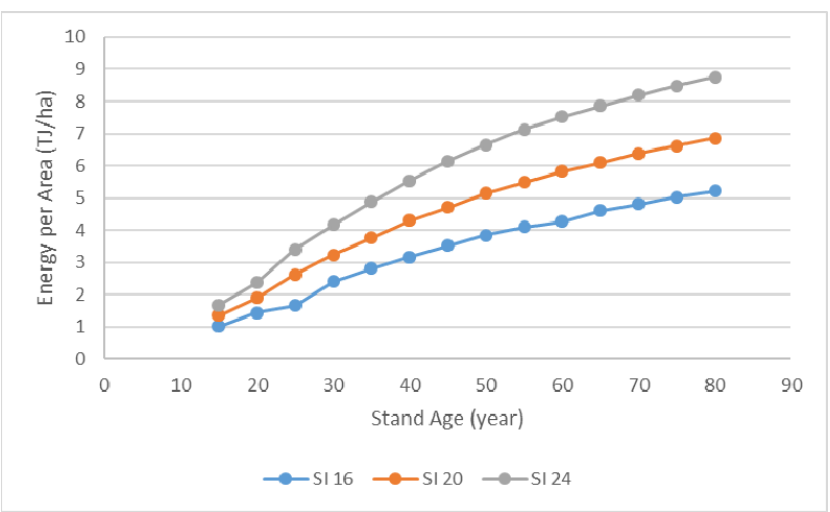

(c)

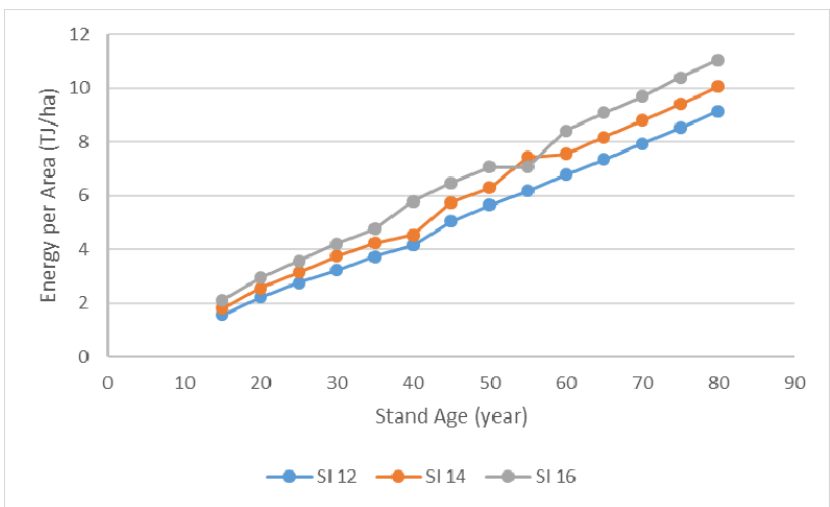

(e)

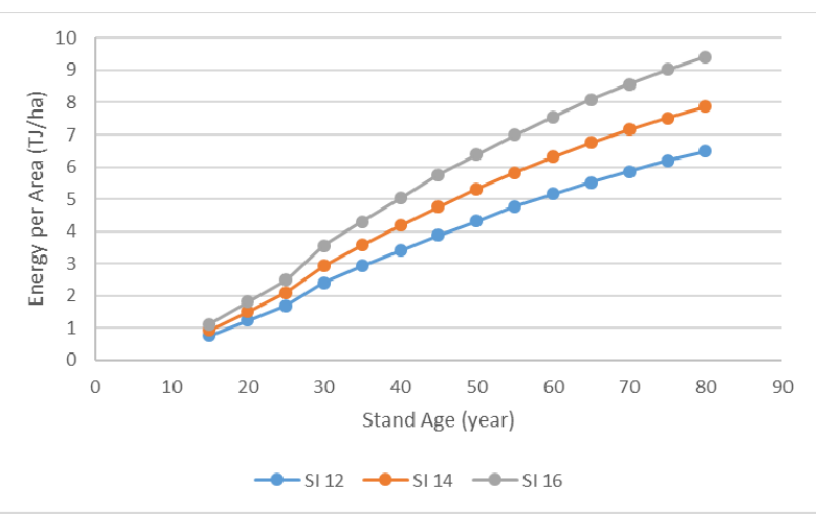

(b)

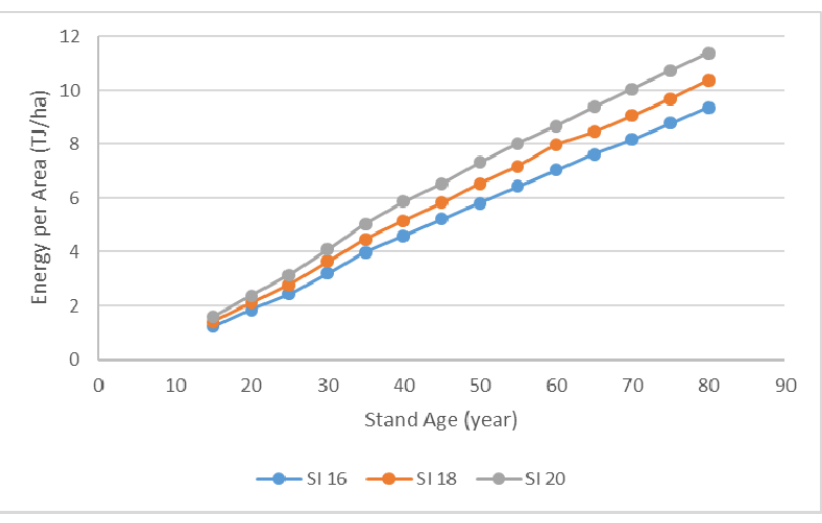

(d)

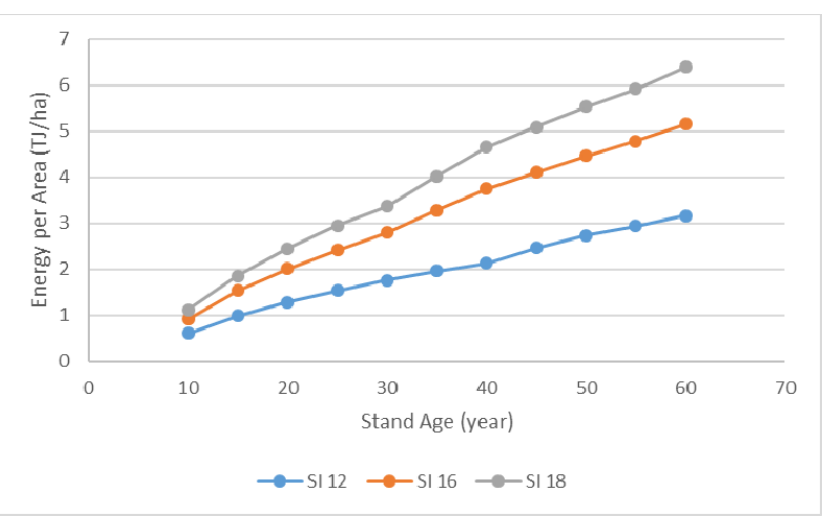

(f)

Fig. 8. Temporal variation of the total energy from the trees per area depending on the site index (SI) representing the environmental conditions of cultivation area: (a) Jungbu local pine; (b) Korean white pine; (c) Japanese larch; (d) oak; (e) red oak; and (f) birch. Due to data availability, the data for each tree are based on the different SIs.

였다. 임목은 수종별로 성장속도가 다를 뿐만 아니라, 재배 기간에 따라 임목의 직경과 수고는 증가하지만 단위 재배 면 적당 개체수가 감소하는 특성을 가지고 있고, 임목의 밀도, 지상부의 바이오매스 비율, 뿌리-줄기의 비율도 다르기 때문 에 재배 기간에 따라 확보할 수 있는 에너지의 양을 예측하는 것은 조림 사업의 계획과 관리를 위해 반드시 필요하다. 또한, 이 방법론은 바이오매스의 생산 가능한 수간재적의 부피 평가 에 활용될 수 있어 재생가능한 친환경 물질인 목재 재료의 총 부피량을 산정하는데 사용할 수 있고, 바이오매스의 생산
가능한 총 질량의 평가도 가능하여 바이오리파이너리의 원료 로 활용될 수 있는 재생가능한 물질 자원의 양을 산정하는데 도 활용될 수 있다. 그러므로, 본 연구는 재생가능한 에너지와 물질을 생산하기 위하여 필요한 원료를 생산하기 위한 임목의 조림 사업의 경제적 타당성 평가에 실용적으로 활용될 수 있 어 기후변화 대응과 지속가능한 사회를 구축하는데 기여할 수 있다. 


\section{Acknowledgements}

이 논문은 2016년도 강원대학교 대학회계 학술연구조성비 (관리번호-520160441)와 2020년도 정부(과학기술정보통신부) 의 재원으로 한국연구재단의 지원을 받아 수행된 사업(NRF2020R1A2C1008532)의 지원으로 이루어졌습니다.

\section{References}

1. Y. Y. Bang, D. S. Lee, S. R. Lim, Analysis of corporate $\mathrm{CO}_{2}$ and energy cost efficiency: the role of performance indicators and effective environmental reporting, Energ. Policy, 133, 110897(2019).

2. J. W. Kook, S. H. Lee, Analysis of biomass energy potential around major cities in South Korea, Appl. Chem. Eng., 26(2), 178-183(2015).

3. Y. S. Kim, Current status and prospects on biofuel conversion technologies and facilities, using lignocellulosic biomass, J. Korean Wood Sci. Tech., 44(5), 622-628(2016).

4. I. T. Kim, K. H. Ahn, Characteristics of coagulation treatment for wood tar waste water in a biomass gasification plant, J. Korean Soc. Environ. Eng., 37(10), 573-577(2015).

5. M. S. Park, Y. W. Chang, Y. K. Jang, Y. N. Chun, Study on a carbon dioxide gasification for wood biomass using a continuous gasifier, J. Korean Soc. Environ. Eng., 36(10), 704-710(2014).

6. J. E. Lee, H. S. Choi, Numerical study on bubbling fluidized bed reactor for fast pyrolysis of waste lignocelluosic biomass, J. Korean Soc. Environ. Eng., 35(10), 710-716(2013).

7. J. J. Kim, Wood pellet fuel and boiler, Magaz. Soc. Air. Cond. Refrig. Eng. Korea, 45(8), 22-31(2016).

8. W. H. Choi, The plan research for a alternative energy resource production increase, Kyung Hee university, Namyangju, Korea, pp. 1-50(2007).

9. N. Y. Jeong, L. H. Kim, The study of economic feasibility of wood pellet in domestic power plants sector, J. Energ. Eng., 19(4), 251-257(2010).

10. S. Y. Myung, Y. J. Eon, J. I. Dong, Y. K. Park, B. S. Kang, J. K. Jeon, Characteristics of thermal decomposition of major components of biomass isolated from wood, J. Ind. Eng. Chem., 15(8), 896-900(2004).

11. Y. S. Kim, A research trend of pretreatment in bioethanol production process with lignocellulosic biomass: a literature review, J. Korean Wood Sci. Tech., 37(3), 274-286(2009).

12. J. S. Bae, Forest transition in Korea: trends, characteristics and implications, J. Korean Soc. For. Sci., 98(6), 659-668 (2009).

13. National Institute of Forest Science, Table of the stem volume, biomass and harvest for forest trees, National Institute of Forest Science, Seoul, Korea(2018).

14. S. K. Jeon, M. Y. Shin, D. J. Jeong, Y. S. Jang, M. S. Kim,
Characteristics of the early growth for Korean white pine(pinus koraiensis sieb. et zucc.) and effects of local climatic conditions on the growth-relation between periodic annual increment and local climatic conditions, J. Korean Soc. For. Sci., 98(6), 88(1), 73-85(1999).

15. J. S. Cho, K. J. Lee, K. S. Ki, A study on restoration plan of cultural forest and change of pinus densiflora forest in Inwangsan(Mt.), Seoul, Kor. J. Env. Eco., 26(2), 219-232 (2012).

16. N. J. Nam, Y. Son, J. S. Kim, R. H. Kim, K. Y. Seo, K. W. Seo, J. W. Koo, J. H. Kyung, I. H. Park, Y. J. Lee, Y. M. Son, K. H. Lee, A study on estimation of biomass, stem density and biomass expansion factor for stand age classes of Japanese larch (larix leptolepis) stands in Gapyeong area, J. Korea Forest. Energ., 25(1), 1-8(2006).

17. U. M. Sainju, B. L. Allen, A. W. Lenssen, R. P. Ghimire, Root biomass, root/shoot ratio, and soil water content under perennial grasses with different nitrogen rates, Field Crops Res., 210, 183-191(2017).

18. National Institute of Forest Science, History and applications of site index, National Institute of Forest Science, Seoul, Korea(2009).

19. National Institute of Forest Science, Estimation of the site index of major trees to take into account climate change, National Institute of Forest Science, Seoul, Korea(2014).

20. National Institute of Forest Science, Estimation of domestic forest biomass, National Institute of Forest Science, Seoul, Korea(2007).

21. H. S. Yang, K. K. Kim, C. W. Lim, J. H. Hyun, RF conversion potential of biomass and mixed plastic waste generated in D city, J. Korea Org. Resour. Recyc. Ass., 26(3), 55-61(2018).

22. S. W. Park, S. J. Lim, T. U. Yu, J. H. Hwang, Pyrolysis characteristics of RDF in pyrolysis chamber of a $30 \mathrm{~kg} / \mathrm{hr}$ scale pyrolysis melting incinerator, J. Korea Soc. Waste Manag., 23(6), 455-464(2006)

23. National Institute of Forest Science, Biomass allometric equations and carbon emission factors of major trees in Korea, National Institute of Forest Science, Seoul, Korea(2014).

24. S. H. Han, W. W. Song, S. J. Shin, Evaluation of typical wood species as the raw material for solid biofuel production by chemical composition analysis, J. Korea Tech. Ass. Pulp Paper Ind., 48(6), 62-71(2016).

\section{Declaration of Competing Interest}

The authors declare that they have no known competing financial interests or personal relationships that could have appeared to influence the work reported in this paper. 


\section{Authors and Contribution Statement}

\section{Heesoo Lee}

Department of Environmental Engineering, School of Architectural, Civil, and Environmental Engineering, Kangwon National University, Chuncheon, Graduate Student, ORCID®: 0000-00015704-490X: Data curation, Data analysis, Project administration, Validation, Visualization, Writing - original draft.

\section{Seong-Rin Lim}

Department of Environmental Engineering, School of Architectural, Civil, and Environmental Engineering, Kangwon National University, Chuncheon, Professor, ORCID @: 0000-0002-5192-0486: Conceptualization, Data analysis, Funding acquisition, Methodology, Project administration, Resources, Supervision, Validation, Visualization, Writing - review and editing. 